\title{
Graftectomiák a debreceni vesetranszplantációs programban
}

\author{
Tóth Fruzsina oh. ${ }^{1}$. Zádori Gergely dr. ${ }^{1}$ \\ Fedor Roland dr. ${ }^{1}$. Kovács Dávid Ágoston dr. ${ }^{1}$ - Kanyári Zsolt dr. ${ }^{1}$ \\ Kincses Zsolt dr. ${ }^{2}$ - Ötvös Csaba dr. ${ }^{1}$ - Damjanovich László dr. ${ }^{1}$ \\ Asztalos László dr. ${ }^{1}$ - Nemes Balázs dr. ${ }^{1}$ \\ ${ }^{1}$ Debreceni Egyetem, Általános Orvostudományi Kar, Sebészeti Intézet, \\ Szervtranszplantációs Nem Önálló Tanszék, Debrecen \\ ${ }^{2}$ Kenézy Gyula Kórház és Rendelőintézet, Általános Sebészeti Osztály, Debrecen
}

\begin{abstract}
Bevezetés: A graftectomia indikációja és pontos időzítése bizonyos esetekben vita tárgya, elsősorban a tüneteket nem okozó, már nem múködő graftok esetén. Célkitüzés: A szerzők átfogó képet kívántak adni a debreceni veseátültetési programban elvégzett graftectomiákról. Módszer: Retrospektív vizsgálattal elemezték a 2004. január 1. és 2015. december 31. között veseátültetett betegek adatait. Áttekintették a graftectomiák indikációit, időzítését, szövődményeit, továbbá összehasonlították a korai és késői graftectomiákat. Eredmények: A vizsgált időszakban 480 veseátültetés történt. Közülük 55 betegnél (11\%) történt graftectomia. A gyakoribb indikációk a következők voltak: krónikus allograft-nephropathia (47\%), artériás keringési zavar (13\%), ureterszövődmények (9\%). A grafteltávolítás 22 betegnél (40\%) akut, 33-nál (60\%) tervezett volt. A graftectomiák 24\%-a a transzplantáció után 30 napon belüli, 76\%-a késői volt. Korai graftectomiát túlnyomórészt artériás keringészavar (31\%), a későiek többségét (62\%) krónikus allograftnephropathia miatt végezték. Következtetések: A vizsgált időszakban a graftectomiák leggyakoribb oka krónikus allograft-nephropathia volt. Az esetek döntő többségében elektív mütét történt. A szakirodalomban közöltekhez hasonlóan a szerzők a korai és késői graftectomiák jellemzőit eltérőnek találták. Orv. Hetil., 2016, 157(24), 964-970.
\end{abstract}

Kulcsszavak: vesetranszplantáció, graftelégtelenség, veseallograft-túlélés, graftectomia

\section{Allograft nephrectomy - a single-center experience}

Introduction: Indication and timing of allograft nephrectomy is still uncertain in some cases. Aim: The aim of the authors was to summarize their experience with graftectomies. Method: Data from patients who underwent kidney transplantation between January 1, 2004 and December 31, 2015 were retrospectively analyzed. Frequency, indications, timing, complications as well as early and late allograft nephrectomies were reviewed. Results: From 480 renal transplants, 55 graftectomies were performed (11\%). Frequent indications included chronic allograft nephropathy (47\%), arterial blood supply complications (13\%), ureter complications (9\%). 22 cases (40\%) of allograft nephrectomies were urgent while 33 cases $(60 \%)$ were elective. $24 \%$ of graftectomies were performed within 30 days after transplantation and $76 \%$ thereafter. Conclusions: The main indications for early graftectomies were arterial complications $(31 \%)$ and chronic allograft nephropathy $(62 \%)$ in cases of late graftectomies. The majority of the graftectomies were elective. Leading indication was chronic allograft nephropathy. Early and late graftectomies have different characteristics.

Keywords: kidney transplantation, graft rejection, graft survival, nephrectomy

Tóth, F., Zádori, G., Fedor, R., Kovács, D. Á., Kanyári, Zs., Kincses, Zs., Ötvös, Cs., Damjanovich, L., Asztalos, L., Nemes, B. [Allograft nephrectomy - a single-center experience]. Orv. Hetil., 2016, 157(24), 964-970.

(Beérkezett: 2016. április 15.; elfogadva: 2016. április 28.) 


\section{Rövidítések}

ARE = akut rejectiós epizód; CAN = krónikus allograft-nephropathia; $\mathrm{CMV}=$ cytomegalovirus; $\mathrm{DIC}=$ disszeminált intravascularis coagulatio; DGF $=($ delayed graft function $)$ veseátültetést követő 1 héten belül legalább 1 dialíziskezelés; DSA = donorspecifikus antitest; $\mathrm{GE}=$ grafteltávolítás; PRA $=$ panelreaktív antitest; ReKT = retranszplantáció

A veseátültetés utáni graftelégtelenség aránya az első évben $7-10 \%$-ra, a további években pedig 3-5\%-ra tehető [1]. A már nem múködő vese eltávolításának (graftectomia) indikációja nem abszolút. A témakör napjainkban is vitatott kérdés a transzplantációval foglalkozók körében, különösen azokban az esetekben, amikor a már nem funkcionáló átültetett vese nem okoz klinikai tüneteket [2].

A szakirodalomban számos közlemény szól a graftectomia ellen. Bizonyított, hogy a helyben hagyott, de beszúkült glomeruláris filtrációs aktivitással rendelkező vese esetén még fennállhat bizonyos mértékü residualis funkció. Ilyen például az eritropoetintermelés, részvétel a D-vitamin szintézisében vagy a folyadékháztartás szabályozásában. Ezek közül talán a megmaradó diuresis a legfontosabb, mert ez felmenti a beteget a folyadékbevitelre vonatkozó megszorítástól [3]. Kimutatták azt is, hogy a beültetett vese egyfajta „szivacsként” funkcionálva megkötheti a recipiens szérumában keringő donorspecifikus, panelreaktív antitesteket. Azoknál a betegeknél, akiknél nem távolították el az első vesegraftot a második vesetranszplantációt megelőzően, alacsonyabb panelreaktív antitest (PRA-) szinteket mértek, mint azoknál, akik retranszplantáció előtt graftectomián estek át $[4,5]$. A már hosszabb ideje nem múködő beültetett vese eltávolítása ellen szól az is, hogy a heges környezetben, az urémiás állapot miatt vérzékeny és egyébként is anaemiás betegnél, az alsó végtagot ellátó erek környezetében végzett preparálás esetén fennáll bizonyos kockázat a posztoperatív vérzés, tályog és egyéb sebgyógyulási zavarok tekintetében [6]. A graftectomia után kialakuló leggyakoribb posztoperatív szövődmények a vérzés, sebfertőzés, haematoma, tályog, lymphocele, haematuria és fistulaképződés, ritkábban az ezek talaján kialakuló szepszis [7].

Számos szakirodalmi forrást találhatunk azonban, amelyek a graftectomia mellett foglalnak állást. Az in situ, de már nem vagy beszúkülten múködő vese krónikus infekció forrása lehet. Eltávolításával tehát mind az infekció, mind a graft által fenntartott folyamatos immunológiai stimulus megszűnik. Az immunszuppresszió, annak minden mellékhatásával együtt, azonnal megszüntethető, szemben a nem eltávolított vese esetén, ahol ennek teljes leépítését hónapok, akár több mint egy év alatt végzik el. A nem múködő, de in situ graftban a lassan beszúkü̈lő, de még intakt keringés mellett necrosis kezdődhet, és így a vese potenciális vérzésforrássá válhat.
Graftectomia után a felszabaduló fossa iliaca - inkább elviekben - egy potenciális harmadik transzplantációra is alkalmassá válik [3]. Egyes kutatások, köztük egy, a Debreceni Egyetem Klinikai Központjában végzett vizsgálat is, arra az eredményre jutottak, hogy a graftectomizált betegek jobb túléléssel bírnak $[8,9]$.

A graft eltávolításának leggyakoribb okai között szerepelnek immunológiai okok (hiperakut, akut, illetve krónikus rejectio), keringési zavarok (leggyakrabban arteria renalis thrombosis), infekció, és ezt követik egyéb, ritkábban előforduló indikációk [3]. Az indikációs kör öszszefüggést mutat a graftectomia időzítésével is [10]. Célunk volt, hogy - több vesetranszplantációs centrumhoz hasonlóan - mi is átfogó képet adjunk az intézetünkben végzett graftectomiákkal szerzett tapasztalatokról.

\section{Módszer}

Retrospektív kutatásunk során a 2004. január 1. és 2015. december 31. között a Debrecenben vesetranszplantált betegek adatait vizsgáltuk. Az adatgyüjtés papíralapú és elektronikus (MedSolution) betegdokumentációk alapján történt, amelyeket egységes adatbázisba gyüjtöttünk össze. A statisztikai elemzéseket az SPSS 22.0 programmal végeztük. Az eredményeket szignifikánsnak vettük, ha $\mathrm{p}<0,05$.

Vizsgáltuk a graftectomiák arányát, indikációját, időzítését, posztoperatív szövődményeit és halálozását. Ezen szempontok szerint összehasonlítottuk a korai és késői graftectomiákat. Korainak definiáltunk minden olyan grafteltávolítást, amely a vese beültetésétól számított 30 napon belül történt. A 30 napon túl végzett graftectomiákat a késői csoportba soroltuk.

A témakörhöz kapcsolódóan a szakirodalomban közöltek alapján összehasonlítottuk az azonos időintervallumban végzett második vesebeültetéseket aszerint, hogy megtörtént-e megelőzően az első, de már nem múködő beültetett vese eltávolítása. Ezekben az esetekben a vese- és betegtúlélést vizsgáltuk.

Az indikációk között szereplő krónikus allograftnephropathia (CAN) megfogalmazás alatt azokat a betegeket értettük, akiknél a fokozatosan beszúkülő graftvesemúködés miatt végzett percutan biopszia irreverzibilis, hegesedéssel járó nephropathiát igazolt. A CAN szövettani diagnózis, amelyet régen a Banff-kritériumok alapján osztályoztak. A kritériumrendszerből azonban kikerült ez az elnevezés, helyette a szakirodalom a 'nem specifikus interstitialis fibrosis és tubularis atrophia - IF/ TA NOS' elnevezést használja. Kutatásunkban azért maradtunk mégis a CAN elnevezésnél, mert betegeink szövettani leleteinek nagy része ezt tartalmazta.

Kombinált keringési zavarként definiáltuk azokat az eseteket, ahol képalkotó vizsgálatokkal mind artériás, mind vénás keringési zavar igazolódott. 


\section{Eredmények}

A vizsgált időszakban Debrecenben 480 vesetranszplantáció történt. A beültetett vesék közül összességében 94 (20\%) múködése szúkü̈lt be vagy szúnt meg véglegesen. A nem múködő graftok 41\%-a, azaz 39 helyben (in situ) maradt, míg 55 vese (59\%) eltávolításra került. A graftectomizált esetek az összes transzplantált beteg $11 \%$-át te-

1. táblázat Intézetünkben végzett graftectomiák indikációi és megoszlásuk

\begin{tabular}{lc}
\hline Indikáció & No. (\%) \\
\hline Krónikus allograft-nephropathia (CAN) & $26(47 \%)$ \\
Artériás keringészavar & $7(13 \%)$ \\
Ureterszövődmények & $5(9 \%)$ \\
Kezelésre refrakter akut rejectio & $4(7 \%)$ \\
Vena renalis thrombosis & $2(4 \%)$ \\
Kombinált keringési zavar & $2(4 \%)$ \\
Hiperakut rejectio & $2(4 \%)$ \\
Infekciós gócként szereplő donorvese & $2(3 \%)$ \\
Előkészület 3. vesetranszplantáció előtt & $1(2 \%)$ \\
Vascularis hypertonia & $1(2 \%)$ \\
Szepszis, DIC & $1(2 \%)$ \\
Megbízható dokumentáció nem állt rendelkezésre & $2(3 \%)$ \\
\hline
\end{tabular}

DIC = disszeminált intravascularis coagulatio.

2. táblázat | Korai és késối graftectomiák összehasonlítása

\begin{tabular}{|c|c|c|c|}
\hline & $\begin{array}{l}\text { Korai } \\
\text { graftectomia } \\
(\mathrm{n}=13)\end{array}$ & $\begin{array}{l}\text { Késói } \\
\text { graftectomia } \\
(\mathrm{n}=42)\end{array}$ & p-érték \\
\hline Átlagéletkor & $\begin{array}{l}42,32 \\
(22-66)\end{array}$ & $\begin{array}{l}44,34 \\
(16-67)\end{array}$ & n. s. \\
\hline Férfi/nő & $\begin{array}{l}6 / 7 \\
(46 / 54 \%)\end{array}$ & $\begin{array}{l}26 / 16 \\
(62 / 38 \%)\end{array}$ & n. s. \\
\hline DGF & $6(46 \%)$ & $15(37 \%)$ & n. s. \\
\hline $\begin{array}{l}\text { Posztoperatív szövődmény } \\
\text { GE után }\end{array}$ & $4(31 \%)$ & $9(21 \%)$ & n. s. \\
\hline $\begin{array}{l}\text { Posztoperatív mortalitás } \\
\text { GE után }\end{array}$ & $3(23 \%)$ & $4(10 \%)$ & n. s. \\
\hline $\begin{array}{l}\text { Graftectomiát követően } \\
\text { reKT }\end{array}$ & $4(31 \%)$ & $5(12 \%)$ & n. s. \\
\hline $\begin{array}{l}\text { Akut rejectio veseátülttetést } \\
\text { követő } 30 \text { napon belül }\end{array}$ & $8(62 \%)$ & $8(19 \%)$ & $<0,01$ \\
\hline $\begin{array}{l}\text { Graftectomia akut } \\
\text { körülmények között }\end{array}$ & $13(100 \%)$ & $9(21 \%)$ & $<0,01$ \\
\hline $\begin{array}{l}\text { Visszatérés dialízisre } \\
\text { graftectomia előtt }\end{array}$ & $0(0 \%)$ & $33(79 \%)$ & $<0,01$ \\
\hline $\begin{array}{l}\text { Graftectomia előtt } \\
\text { vesebiopszia történt }\end{array}$ & $3(23 \%)$ & $31(74 \%)$ & $<0,01$ \\
\hline
\end{tabular}

DGF = delayed graft function; legalább 1 dialíziskezelés veseátültetést követő 1 héten belül; $\mathrm{GE}=$ grafteltávolítás; $\mathrm{n}$. $\mathrm{s}$. = nem szignifikáns; $\mathrm{ReKT}=$ retranszplantáció. szik ki. A betegek átlagéletkora 43,8 év (legfiatalabb $15,6$, legidősebb 66,8$)$ volt, 32 férfi $(58 \%)$ és 23 nő $(42 \%)$. A grafteltávolítás 43 esetben az első $(78 \%)$, míg 12 esetben a második $(22 \%)$ vese beültetése után történt. Kilenc beteg (16\%) anamnézisében szerepelt az aktuális vesetranszplantációt megelőző graftectomia.

Korai graftectomiára 13 páciensnél (24\%), míg későire 42 betegnél $(76 \%)$ került sor. A késői csoportot tovább bontva, közülük 7 (17\%) a vesetranszplantációt követő egy éven belül, míg 35 (83\%) egy éven túl történt. Az 55 veseeltávolító mútét közül 22-t (40\%) akutan, míg 33-at (60\%) tervezetten, elektív mútétként végeztek el.

Az összes graftectomia indikációinak megoszlását az 1 . táblázatban tüntettük fel, a korai és késői graftectomiák indikációinak összehasonlítását az 1 . ábrán mutatjuk be. Valamennyi esetet figyelembe véve, a nem múködő transzplantált vesék eltávolítására átlagosan 34 hónappal a vesebeültetést követően került sor. A korai csoportban ez átlagosan 12 nap, míg a későieknél átlagosan 45 hónap volt. A további összehasonlítási szempontokat a 2 . táblázat tartalmazza.

Posztoperatív szövődmény az összes graftectomia után 13 esetben $(24 \%)$ jelentkezett. Előfordult haematoma $(8 ; 62 \%)$, sebgyógyulási zavar $(4 ; 31 \%)$ és a mútéti területen kialakult folyadékgyülem $(1 ; 7 \%)$. A szövődmény elhárítása céljából 7 páciensnél (54\%) történt sebészi beavatkozás.

A posztoperatív mortalitás az összes graftvese-eltávolításon átesett betegre vonatkoztatva $13 \%$ (7 páciens). A halálozáshoz vezető okok között szerepel DIC, CMVinfekció és cardiovascularis sokk.

A korábban leírtak alapján külön megvizsgáltuk a második veseátültetésen átesett betegek adatait abból a szempontból, hogy ezt megelózte-e az első beültetett vese eltávolítása vagy nem.

A vizsgált időintervallumban az összes (480) beteg közül 60 betegnél történt második vesetranszplantáció. Közülük 38 páciens esetén (63\%) az első, már nem múködő vese megelőzően eltávolításra került, a többieknél (22 beteg, 37\%) in situ első graft mellett került sor a második veseátültetésre. Összehasonlítottuk ezt a két alcsoportot. A második vesetranszplantációt megelőzően graftectomizált 38 beteg közül 9 páciensnél (24\%) ment tönkre a második beültetett vese is. Ezek a betegek ismét visszakerültek dialízisre, átlagosan 41 hónappal a második veseátültetés után. Azok közül, akiknél az első graftot nem távolították el (22 fó) a második veseátültetés elôtt, csak 4 betegnél (18\%) volt sikertelen a második beültetés. Ezek a betegek átlagosan 25 hónappal a (második) mútét után kerültek vissza dialízisre.

$\mathrm{Az}$ első csoportban (akik graftectomia után mentek második beültetésre) a vesemúködés megszúnése után 6 betegnél $(66 \%)$ végezték el a második vese eltávolítását is, átlagosan 46 hónappal a második transzplantációt követôen. A követési idő́n belül ennek a csoportnak a teljes mortalitása 16\% volt (6 fó). A halálozások átlagosan 38 hónappal a második veseátültetés után történtek. 


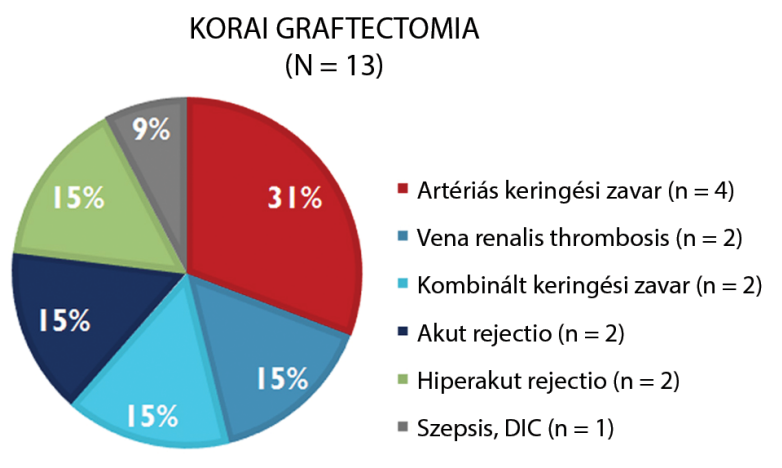

1. ábra

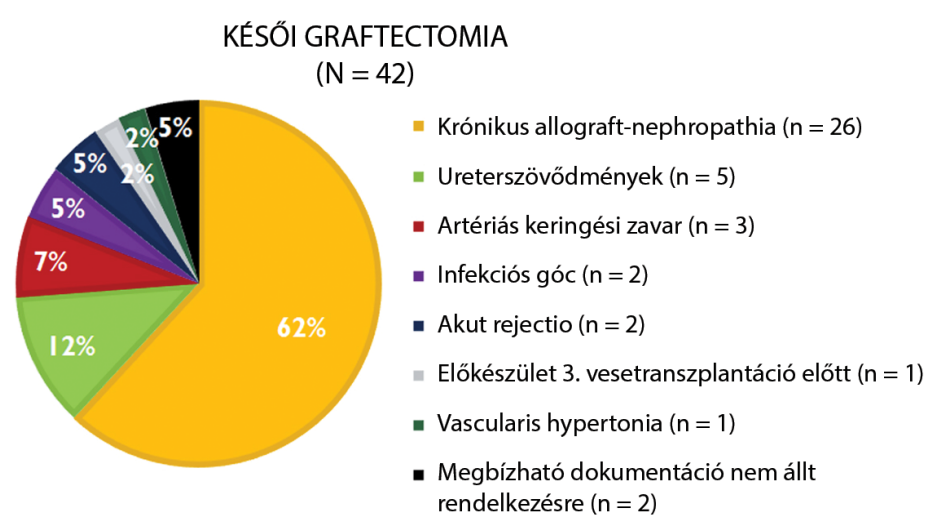

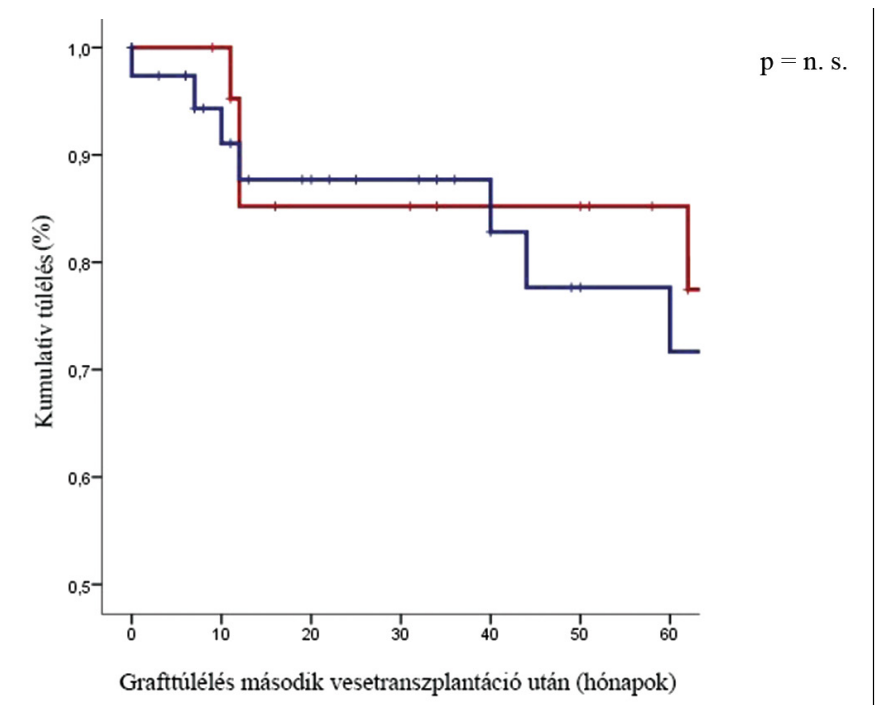

- Retranszplantáció előtt grafteltávolitás történt

- Retranszplantáció előtt nem történt grafteltávolitás

2. ábra Graftectomizált és nem graftectomizált betegek grafttúlélésének
összehasonlítása második vesetranszplantációt követően
Ábramagyarázat: Két betegcsoport túlélését hasonlítottuk ösz-
sze: az első csoport (kék) tagjainál a második vesetranszplantá-
ció előtt eltávolításra került a nem múködő első graft, míg a
második csoportnál (piros) nem. Látható, hogy az első csoport
grafttúlélése az idő előrehaladtával nagyobb mértékben csök-
ken, mint a másodiké, de a különbség nem szignifikáns $(p>0,05)$

A négy beteg közül, akiknél a második veseátültetés in situ első graft mellett történt, de a második vese múködése is megszűnt, végül kettőnél $(50 \%)$ került sor a második vese eltávolítására, átlagosan 20 hónappal a második veseátültetést követően. Az előzőleg nem graftectomizált csoport összmortalitása $28 \%$ volt ( 6 fó). Az elhalálozás átlagos ideje 66 hónap volt a második vesebeültetést követően.

Második veseátültetés esetén az 1, 3, 5 és 10 éves kumulatív beteg-, illetve grafttúlélés a két csoportban az alábbi volt. A megelőzően graftectomizált betegeknél $88 \%, 88 \%, 72 \%$ és $57 \%$ (vesetúlélés), valamint 92\%, 84\%,

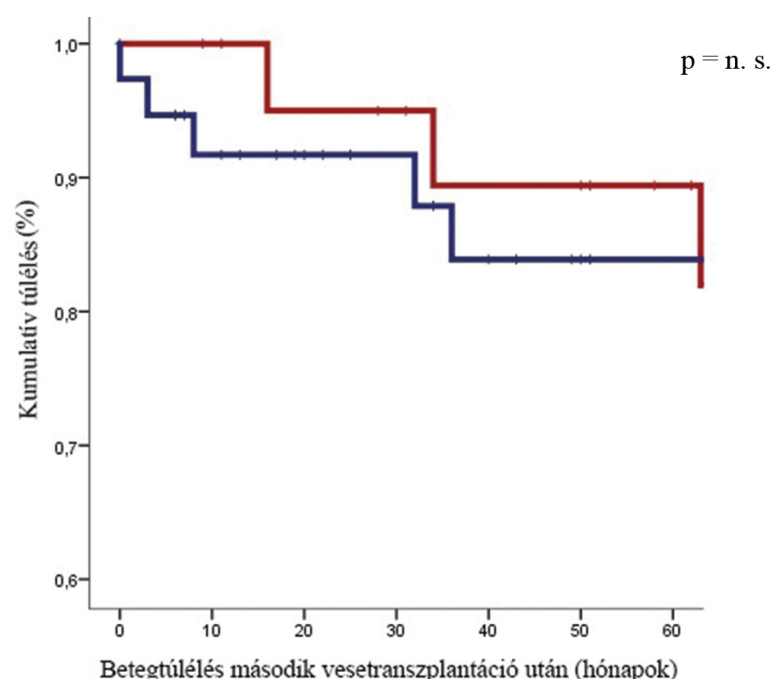

- Retranszplantáció elött grafteltávolitás történt

- Retranszplantáció elött nem történt grafteltávolitás

3. ábra Graftectomizált és nem graftectomizált betegek túlélésének ösz-
szehasonlítása második vesetranszplantációt követően
Ábramagyarázat: Két betegcsoport túlélését hasonlítottuk össze:
az első csoport (kék) tagjainál a második vesetranszplantáció
előtt eltávolításra került a nem múködő első graft, míg a máso-
dik csoportnál (piros) nem. Látható, hogy a második csoport az
első 5 év során jobb túléléssel bír, mint az első, de statisztikailag
a különbség nem szignifikáns (p>0,05)

$84 \%$ és $84 \%$ (betegtúlélés), míg a megelőzően nem graftectomizált betegeknél 85\%, 85\%, 85\% és 76\% (grafttúlélés) és $100 \%, 94 \%, 94 \%$ és $53 \%$ (betegtúlélés). A különbségek a graftectomizált és nem graftectomizált csoport között nem szignifikánsak.

A túlélési görbéket a 2. és 3. ábrán ábrázoltuk.

\section{Megbeszélés}

Kutatásunk során összefoglaltuk az intézetünkben végzett graftectomiákkal szerzett tapasztalatokat. A 12 éves időperiódus során összesen 480 vesebeültetés történt, 
amelyek közül 55 esetben (11\%) került eltávolításra a beültetett, de már nem múködő vese. A graftectomia előfordulása a szakirodalomban közöltek alapján széles skálán mozog: az összes transzplantációra vonatkoztatva 4,5\% [11] és 84,5\% [12] gyakoriságot is közöltek. Bár az egyes centrumok által közölt eredmények összehasonlítása a különböző statisztikai módszerek és eltérő betegkövetési idő miatt nehéz, intézményünk 11\%-os nonkumulatív incidenciája összhangban van több forrás adataival (Secin és mtsai 14,8\% [3], Rosenthal és mtsai $10,5 \%[13])$.

A legtöbbször előforduló indikáció a CAN volt (47\%). $\mathrm{Ez}$ az eredmény egyezik más centrumokban tapasztaltakkal, mint például Secin és mtsai (58,2\%) [3], illetve Bonilla és mtsai (58,5\%) [7] eredményeivel. Az artériás thrombosis minden szervátültetés elkerülendő és nem kívánt szövődménye. Májátültetés után közvetlen befolyással van a recipiens életkilátásaira is [14]. Ariyarathenam és mtsai kutatásában a graftectomia leggyakoribb indikációja a graft thrombosisa volt [15], ezen belül is a vena renalis thrombosis túlsúlyával. Ez a mi intézetünkben mindössze két páciensnél fordult elő. Míg a szakirodalomban viszonylag gyakori indikációként szerepelnek a de novo tumorok $[2,9]$, a vizsgált időperiódusban nem találkoztunk ilyen esettel. Ennek oka lehet a különböző immunszuppressziós kezelés, mivel 2014 előtt intézetünkben nem volt rutinszerú az indukciós terápia alkalmazása, amely ismert rizikófaktora a malignus tumorok kialakulásának szervátültetés után [16].

Egy betegünknél donorpatkóvesével végzett vesetranszplantáció technikailag sikeres volt ugyan, de később, feltehetően az egyik beültetett donorureter végének (úgynevezett tip) nekrózisa talaján varratelégtelenség, vizeletcsorgás és progrediáló szepszis alakult ki, amely végül a graft eltávolítását tette szükségessé [17].

Centrumunkban a graftectomiák többsége késői és elektív mütétként zajlott. A korai és késői csoport összehasonlításakor az indikációs kört más kutatásokkal egyetértésben $[2,10,18]$ alapvetően eltérőnek találtuk. A korai nephrectomiák leggyakrabban artériás keringési zavar miatt történtek, amit egyenlő arányban követett a vénás és kombinált keringési zavar, valamint hiperakut és akut rejectio. Ezzel ellentétben a késői graftectomiák döntő többségére CAN miatt került sor. A késői műtétek indikációi között szerepeltek még az ureterszövődmények (hegesedés, beszúkülés) és artériás stenosis.

Bár a korai graftectomiák esetében a posztoperatív szövődmények és mortalitás valamivel magasabb arányát észleltük, mint a késői csoportban, a különbség nem volt szignifikáns, ellentétben Sun és mtsai [10], illetve Freitas és mtsai [18] közléseivel. Viszont más szerzők (Mazzucchi és mtsai) inkább a késői graftectomiák után számoltak be magasabb szövődményarányról, amelyet a késői mútétek technikailag nehezebb voltával magyaráztak [6]. Centrumunkban a graftectomia után leggyakrabban jelentkező szövődmény a vérzés és haematoma volt, hasonlóan Grochowiecki és mtsai [19] eredményeihez.
Szintén nem találtunk szignifikáns eltérést a két csoport között a retranszplantációk arányában, de gyakrabban történt második veseátültetés korai graftectomiák után. Ennek oka, hogy a beültetett vese korai eltávolítására általában röviddel a beültetés után, technikai szövődmény miatt kerül sor, így a beteg nem immunizálódik [20] és megfelelő orvos-beteg kommunikáció mellett motivált marad. Ezzel ellentétben a késői graftectomiák leggyakrabban immunológiai ok miatt történnek (CAN), a beteg az évek során immunizálódik, illetve 12-18 év megfelelő vesemúködés után lehet, hogy előrehaladott életkorúvá is válik egy második mútéthez, vagy elveszíti motivációját. Johnston és mtsai retrospektív kutatásukban összefüggést találtak a graftectomia időzítése és az újabb transzplantáció kimenetele között. Arra az eredményre jutottak, hogy a korai veseelégtelenség miatt végzett grafteltávolítás csökkenti az esélyt, hogy a retranszplantáció után újra hasonló helyzet alakuljon ki, míg a késői, lassan kialakuló vesemúködés-beszúkülés esetén a graft in situ hagyása bizonyult protektívebbnek. Azt is leírták azonban, hogy a veseelégtelenség kockázata nem a megnövekedett grafttúlélés, hanem múködő vese mellett észlelt alacsonyabb halálozási arány miatt csökkent [21].

A korai és késői csoport között - érthetően - szignifikáns különbséget találtunk a mütét sürgőssége tekintetében: minden korai graftectomia akut mútétként zajlott, míg a későiek többsége elektíven. Szignifikánsan magasabb volt a vesebeültetést követően, 30 napon belül jelentkező akut rejectio aránya is azok között, akik később korai graftectomián estek át, annak ellenére, hogy az ARE csak az indikációk töredéke volt a korai csoport esetében. A vesebiopsziával alátámasztott diagnózisok arányát szignifikánsan magasabbnak találtuk a késői graftectomiák között. Ennek érthető magyarázata, hogy ebben a csoportban a fokozatosan beszúkülő vesemúködés mellett, az utánkövetés során tervezetten történt a szövettani mintavétel. A késői graftectomiák nagy részét krónikus allograft-nephropathia miatt végeztük, és magasabb volt azoknak a betegeknek az aránya is, akik a vese eltávolítása előtt már visszatértek a dialízisprogramba. A korai időszakban végzett mütétekre főleg keringési zavar miatt került sor.

Bizonyított, hogy a beültetett, de már nem múködő donorvese eltávolításának szerepe van az alloszenzitizációban retranszplantáció előtt. Emiatt az érintett beteghez nehezebb megfelelő, azaz negatív keresztpróbával rendelkező donort társítani. Ez megnöveli a várólistán töltött időt is [22]. Valószínúsíthető, hogy a már nem múködő vesegraft immunológiai szivacsként funkcionálva megköti a keringő antitesteket. Ezt a feltevést bizonyítja Del Bello és mtsai közlése, ahol már 15 nappal a graftectomia után de novo DSA volt kimutatható. Ez a DSA preformált eredetére utal [23]. Több más kutatócsoport is beszámolt emelkedett PRA-szintről graftveseeltávolítást követően $[4,5]$. Ezek a faktorok fontos sze- 
reppel bírhatnak a második vesetranszplantáció utáni vese- és betegtúlélésben.

Megvizsgáltuk a 12 éves periódus alatt második vesebeültetésen átesett betegek graft- és betegtúlélését aszerint, hogy megtörtént-e az első, már nem múködő donorvese eltávolítása a második beültetés előtt.

Retranszplantált betegeink 63\%-ánál végeztük el megelőzően az első vese graftectomiáját, ami korrelál Dinis és mtsai 60,3\%-os [4] és Schleicher és mtsai 73\%-os [24] eredményeivel. Az előzőleg graftectomizált betegeknél a második veseátültetés után valamivel magasabb arányban észleltük ismét a második vese múködésének megszűnését. Ez megfelelhet az előbb említett teóriának. Ezen betegek közül ugyancsak többen estek át a második veseátültetéshez tartozó újabb graftectomián, mint azok, akiknél nem történt meg az első graft eltávolítása sem (24\% vs. 18\%). A különbség azonban nem volt szignifikáns. Más szerzők statisztikailag jobb vesetúlélést közöltek a második transzplantáció előtt nem graftectomizált betegek esetében, de ez a vizsgálat a miénkhez képest jelentősen nagyobb esetszámon alapult [25]. A betegtúlélést vizsgálva sem kaptunk szignifikáns különbséget a két csoport között, szemben más forrásokkal, ahol azt találták, hogy a graftectomia javítja a retranszplantáció utáni túlélést $[8,9]$. Saját vizsgálatainknál a trendek egyeztek. A statisztikai különbözőség hiányát feloldhatja, ha magasabb esetszám ismeretében, prospektív DSAszüréssel kiegészítve, néhány év múlva megismételjük az elemzésünket.

\section{Következtetések}

Elmondhatjuk, hogy centrumunkban az átültetés után észlelt, irreverzibilis vesekárosodás miatt, kényszerűségből végzett graftectomiák többsége több mint 30 nappal a transzplantáció után, elektíven történt, az esetek nagy részében krónikus allograft-nephropathia miatt. A korai és késői graftectomiákat összehasonlítva különbözőnek találtuk a két csoport indikációs körét, a műtétek sürgősségét, korai akut rejectio előfordulását, a dialízisre való visszatérés arányát, valamint a graftectomiát megelőző, annak indikációját igazoló vesebiopszia megtörténtét. A retranszplantációt követő graft- és betegtúlélésben nem találtunk szignifikáns különbséget az előzőleg graftectomizált, illetve nem graftectomizált betegcsoport között, de a trendek megegyeznek a nemzetközi közlésekkel.

Anyagi támogatás: A közlemény megírása, illetve a kapcsolódó kutatómunka anyagi támogatásban nem részesült.

Szerzői munkamegosztás: T. F.: Adatgyüjtés, adatelemzés, szövegezés, táblázat- és ábraszerkesztés, irodalomkutatás, eredmények összevetése a közlésekkel. Z. G.: Tanácsadás adatelemzésben, statisztikai program kezelésében. F. R.: Mütétek végzése, esetkonzultáció. K. D.
Á.: Mütétek végzése, tanácsadás irodalomkutatásban. Ka. Zs., Ki. Zs.: Mütétek végzése, tanácsadás mütéttechnikai részletekben. Ö. Cs.: Irodalomgyưjtés és interpretálás. D. L.: Tanácsadás szervezési, adatgyüjtési kérdésekben, lektorálás. A. L.: Műtétek végzése, tanácsadás a 2013 előtti szakmai trendekhez. N. B.: Témaválasztás, adatgyüjtés megszervezése, statisztikai feldolgozás, eredmények értelmezése, mútétek végzése, az irodalmi gyưjtés adatainak értelmezése, szövegszerú korrektúra. A cikk végleges változatát valamennyi szerző elolvasta és jóváhagyta.

Érdekeltségek: A szerzőknek nincsenek érdekeltségeik.

\section{Irodalom}

[1] Lamb, K. E., Lodhi, S., Meier-Kriesche, H. U.: Long-term renal allograft survival in the United States: a critical reappraisal. Am. J. Transplant., 2011, 11(3), 450-462.

[2] Akoh, J. A.: Transplant nephrectomy. World J. Transplant., 2011, l(1), 4-12.

[3] Secin, F. P., Rovegno, A. R., del Rosario Brunet, M., et al.: Cumulative incidence, indications, morbidity and mortality of transplant nephrectomy and the most appropriate time for graft removal: only nonfunctioning transplants that cause intractable complications should be excised. J. Urol., 2003, 169(4), 12421246.

[4] Dinis, P., Nunes, P., Marconi, L., et al.: Kidney retransplantation: removal or persistence of the previous failed allograft? Transplant. Proc., 2014, 46(6), 1730-1734.

[5] Khakhar, A. K., Shahinian, V. B., House, A. A., et al.: The impact of allograft nephrectomy on percent panel reactive antibody and clinical outcome. Transplant. Proc., 2003, 35(2), 862-863.

[6] Mazzucchi, E., Nahas, W. C., Antonopoulos, I. M., et al.: Surgical complications of graft nephrectomy in the modern transplant era. J. Urol., 2003, 170(3), 734-737.

[7] Bonilla, A. J., Alfaro, A. G., Henández, J. P., et al.: Review of a transplantectomy series. Transplant. Proc., 2015, 47(1), 81-83.

[8] Szabó, R. P., Klenk, N., Balla, J., et al.: Prognosis of dialysed patients after kidney transplant failure. Kidney Blood Press. Res., 2013, 37(2-3), 151-157.

[9] Ayus, J. C., Achinger, S. G., Lee, S., et al.: Transplant nephrectomy improves survival following a failed renal allograft. J. Am. Soc. Nephrol., 2010, 21(2), 374-380.

[10] Sun, I. O., Hong, Y. A., Park, H. S., et al.: Comparison of the clinical characteristics of renal transplant recipients who underwent early versus late graft nephrectomy. Transplant. Proc., 2013, 45(8), 2953-2956.

[11] Sharma, D. K., Pandey, A. P., Nath, V., et al.: Allograft nephrectomy - a 16 year experience. Br. J. Urol., 1989, 64(2), 122-124.

[12] Toledo-Pereyra, L. H., Gordon, C., Kaufmann, R., et al.: Role of immediate versus delayed nephrectomy for failed renal transplants. Am. Surg., 1987, 53(9), 534-536.

[13] Rosenthal, J. T., Peaster, M. L., Laub, D.: The challenge of kidney transplant nephrectomy. J. Urol., 1993, 149(6), 1395-1397.

[14] Nemes, B., Gaman, G., Gelley, F., et al.: Technical risk factors for hepatic artery thrombosis after orthotopic liver transplantation: the Hungarian experience. Transplant. Proc., 2013, 45(10), 3691-3694.

[15] Ariyarathenam, A., Bamford, A., Akoh, J. A.: Transplant nephrectomy - A single-center experience. Saudi J. Kidney Dis. Transpl., 2015, 26(6), 1108-1112.

[16] Wagner, S. J., Brennan, D. C.: Induction therapy in renal transplant recipients: how convincing is the current evidence? Drugs, 2012, 72(5), 671-683. 
[17] Nemes, B., Kanyári, Z., Zádori, G., et al.: Horseshoe kidney transplantation. Interv. Med. Appl. Sci., 2015, 7(2), 85-89.

[18] Freitas, R., Malheiro, J., Santos, C., et al.: Allograft nephrectomy: a single-institution, 10-year experience. Transplant. Proc., 2015 , $47(4), 992-995$.

[19] Grochowiecki, T., Szmidt, J., Galazka, Z., et al.: Influence of timing of transplant nephrectomy on surgical complications. Transplant. Proc., 2000, 32(6), 1381.

[20] Sener, A., Khakbar, A. K., Nguan, C. Y., et al.: Early but not late allograft nephrectomy reduces allosensitization after transplant failure. Can. Urol. Assoc. J., 2011, 5(6), 142-147.

[21] Johnston, O., Rose, C., Landsberg, D., et al.: Nephrectomy after transplant failure: current practice and outcomes. Am. J. Transplant., 2007, 7(8), 1961-1967.

[22] Pham, P. T., Everly, M., Faravardeh, A., et al.: Management of patients with a failed kidney transplant: Dialysis reinitiation, immunosuppression weaning, and transplantectomy. World J. Nephrol., 2015, 4(2), 148-159.
[23] Del Bello, A., Congy, N., Sallusto, F., et al.: Anti-human leukocyte antigen immunization after early allograft nephrectomy. Transplantation, 2012, 93(9), 936-941.

[24] Schleicher, C., Wolters, H., Kebschull, L., et al.: Impact of failed allograft nephrectomy on initial function and graft survival after kidney retransplantation. Transpl. Int., 2011, 24(3), 284-291.

[25] Tittelbach-Helmrich, D., Pisarski, P., Offermann, G., et al.: Impact of transplant nephrectomy on peak PRA levels and outcome after kidney re-transplantation. World J. Transplant., 2014, 4(2), 141-147.

(Tóth Fruzsina, Debrecen, Móricz Zsigmond körút 22., 4032 e-mail: toth.fruzsina.m@gmail.com)

\section{FELHÍVÁS \\ folyóirat-referátumok beküldésére}

A Semmelweis Egyetem Továbbképző Központjának döntése értelmében

2016. január 1-jétöl folyamatosan orvos-továbbképzési pontokat kaphatnak a nemzetközi, impaktfaktoros folyóiratokban megjelent közlemények rövid összefoglalásának, referátumának beküldői.

Az Orvosi Hetilap hasábjain megjelenő és közlésre elfogadott referátum után 1 pont, félévente maximum 12 továbbképzési pont gyưjithető, amelyet félévente összesitve továbbitunk a továbbképzési központok felé.

Távoktatással szerzett pontokból évente legfeljebb 20 pont számitható be.

Aki továbbképzési pontot kiván gyüjteni, a referátum beküldésekor adja meg pecsétszámát.

Várjuk lelkes, továbbképzési pontokat gyüjteni kívánó referálóink jelentkezését!

\section{A referátum fejlécében az alábbi adatokat kérjük megadni:}

A cikk címe magyarul, zárójelben az angol cím

A szerző(k) neve (vezetéknév, a keresztnevet jelölő betü(k) - 3 szerzőig, háromnál több szerző esetén et al.), a levelező szerző neve, munkahelye és e-mail címe)

A folyóirat neve - a szokásos nemzetközi rövidítés szerint (PubMed), évszám, kötetszám, füzetszám, a cikk kezdő és utolsó oldalszáma

A referátumot elektronikus úton (Editorial Manager vagy e-mail: edit.budai@akademiai.hu) kérjük elküldeni. 